\title{
AFIRMASI FIQH ATAS HUKUM ADAT DAN HUKUM NEGARA
}

\author{
Oleh: \\ Khoirul Anwar \\ Universitas Ibrahimy Situbondo \\ mas_anwar78@yahoo.co.id
}

\begin{abstract}
:
There are many religious practices are found in the construction of fiqh, both 'ubudiyah (vertical relations) and mu'amalah (horizontal relations), which are the results of the adoption of pre-Islamic Arabic traditions. Hajj, umrah, hadd al-zina and stealing, drinking khamr, qishas, diyat, qasamah and 'aqilah, until slavery and polygamy are examples of Arabic traditions (customary law) which are reformulated in the construction of fiqh. In the science of ushul fiqh, tradition gained attention, and even became one of the sources of Islamic law. In the context of life of nation and state, whatever state provisions can also be accommodated by fiqh. Therefore, customary law and also state law can be accommodated by Islam as long as it does not conflict with Islamic vision. And so, Islam does not become rigid and easily accepted by the people, as preached by the Prophet Muhammad SAW in Arab and Walisongo in Indonesia.
\end{abstract}

Keywords: Hukum Adat, Hukum Negara, Fiqh

\section{A. Pendahuluan}

Islam sebagai agama yang dibawa oleh Nabi Muhammad Saw sebagai suatu risalah adalah tunggal. Akan implementasi dari ajaran Islam tersebut dalam perkembangannya menjadi plural. Setidaknya hal itu terjadi setelah Rasulullah wafat yang melahirkan firqah dan madhhab. Pluralisme terjadi karena adanya perbedaan cara berfikir dan situasi yang dihadapi. Dengan demikian, pluralism keberagaam adalah sunnatullah, suatu kewajaran yang harus diterima.

Fiqh merupakan ajaran Islam yang mengatur kehidupan praktis atas dasar dalil-dalil partikular dan digali melalui prosedur ijtihad. Meskipun Rasulullah Saw telah menetapkan dasar-dasar ijtihad untuk melahirkan fiqh dan memberikan contoh dalam kehidupan praktis, namun karena situasi yang berkembang, dan cara berfikir yang beragam, maka lahir pula fiqh yang beragam. Sebagai contoh ketika Sahabat Umar menjabat khalifah. Beliau seringkali melakukan ijtihad yang keputusannya 
berbeda dengan praktek keagamaan yang diterapkan oleh Rasulullah. Produk ijtihad Umar ini memberikan dampak yang luas bagi kehidupan umat Islam saat, sehingga lahir madhhab Umari. Corak madhbab Umar ini memunculkan friksi lain dalam pemikiran dan keberagamaan Islam, yakni madhhab Alawi, yang dimotori oleh sahabat yang berkumpul di sekitar Ali bin Abi Thalib. Dalam perkembangannya kedua madhhab ini kemudian menjadi cikal bakal aliran Iraq (Kufah-Bas\}rah) dan Hijaz (MakkahMadinah). Keduanya sangat berlawanan dalam melakukan ijtihad.

Perbedaan fiqh madhhab Umar dan Alawi tersebut tidak dapat terlepas dari perbedaan cara berfikir dalam ijtihad dan perbedaan situasi yang dihadapi. Seperti yang terjadi pada Hijaz dan Irak. Hijaz merupakan kawasan yang didominasi oleh sahabat mewarisi tradisi kenabian sehingga sangat akrab dengan sunnah. Selain itu Hijaz merupakan daerah yang tergolong tradisional dan belum muncul masalah-masalah baru yang rumit yang tidak dijelaskan oleh nas\} al-Qur'an maupun al-Sunnah. Sementara Iraq merupakan kawasan metropolitan yang mempunyai peradaban dan sistem pemerintahan sendiri, menghadapi kehidupan yang komplek dan beragam persoalan. Dampaknya adalah pemikiran Hijaz cenderung tekstual sehingga berbagai sarjana barat menyebutnya dengan corak ilahiyah. Sementara pemikiran Irak cenderung rasional yang berdampak pada produk yang kontekstual.

Di tengah arus perubahan sosial, kedua aliran ini berkembang dan mengalami metamorforsis serta selalu antagonis. Hal ini menggambarkan kesadaran yang sangat mendalam bahwa fiqh merupakan aturan yang mampu menyelesaikan berbagai persoalan dalam masyarakat. Dengan begitu kajin fiqh merupakan kajian yang sangat strategis dan dinamis. Dampaknya adalah fiqh selalu eksis, dibanding ajaran Islam lain seperti kalam, filsafat maupun tasawuf.

Ekspansi Islam ke berbagai kawasan atau wilayah merupakan salah satu penyebab perubahan sosial dalam masyarakat Islam. Hal ini sudah tentu juga berimplikasi kepada kontruksi fiqh. Merujuk kepada kaidah Muhammad Az-Zaqa' bahwa perubahan hukum itu terjadi karena adanya perubahan masa dan tempat. Selain itu adapula kaidah bahwa eksistensi hukum itu tergantung illat (sebab). Oleh karena itu, kawasan masyarakat Islam yang sebelumnya memiliki sistem nilai dan budaya bahkan mungkin juga tata aturan kehidupan bernegara yang berbeda dengan Islam sudah tentu menimbulkan kerumitan bagi umat dalam kehidupan beragama, antara mengikuti hukum Islam (figh), ataukah mengikuti hukum budaya dan atau negara. Pilihan sikap beragama dengan model apapun, hal ini 
menunjukkan keragaman atau pluralisme dalam Islam. Papar ini hendak menguraikan relasi fiqh dengan hukum adat dan atau hukum negara.

\section{B. Konstruksi Fiqh}

\section{Fiqh Versus Hukum Adat}

Menurut Abdul Halim, hukum adat adalah hukum yang tidak tertulis. Ia tumbuh, berkembang dan hilang sejalan dengan pertumbuhan dan perkembangan masyarakat. Tujuan adanya hukum adat adalah menyelenggarakan kehidupan masyarakat yang aman, tentram dan sejahtera. Hukum adat ini berasal dari keputusan penguasa adat, kesadaran hukum yang hidup dalam masyarakat adat, dan rasa malu yang ditimbulkan oleh karena fungsinya sebagai sistem nilai dalam masyarakat adat atau karena upaya-upaya lain yang pada akhirnya akan mengenai orang yang bersangkutan apabila ia tidak mematuhi hukum yang ada. Bidang yang diatur oleh hukum adat diantaranya mengenai asas-asas kerukunan, kepatuhan, keselarasan dalam pergaulan dan yang bersifat religio magis. Dalam hukum adat tidak mengenal hukum perdata dan publik ${ }^{1}$. Pertanyaannya adalah bagaimana posisi hukum adat tersebut ketika dihadapkan pada hukum Islam (fiqh)

Dalam konstruksi figh banyak ditemukan praktek-praktek keagamaan, baik 'ubudiyah (hubungan vertikal) maupun mu'a>malah (hubungan horizontal), yang merupakan hasil adopsi tradisi Arab praIslam. Ibadah haji, umroh, hadd al-zina dan mencuri, minum khamr, qis\}a>s, diyat, qasamah dan 'a>qilah, sampai perbudakan dan poligami ${ }^{2}$ merupakan contoh dari tradisi (hukum adat) Arab yang dirumuskan ulang dalam konstruksi fiqh. Dalam terminologi ilmu ushul fiqh ditegaskan bahwa hukum adat (tradisi masyarakat) dapat dijadikan sebagai salah satu sumber hukum Islam, yang disebut dengan istilah 'urf. Dengan demikian nampak jelas bahwa hukum Islam dan hukum adat dapat dikompromikan sebagai suatu rujukan kehidupan beragama. Meskipun demikian, tidak semua hukum adat dapat diterima oleh fiqh. pertanyaannya adalah 'urf bagaiamanakah yang diakomodasi oleh fiqh. Jawaban tersebut dirunut dari definisi, ketentuan hukum adat, pola akomodasi dan solusi atas perbedaan antara fiqh dan hukum adat.

${ }^{1}$ Abdul Halim dalam buku Cendekiawan Fiqh Berbicara, 47-53.

${ }^{2}$ Khlmil 'Abd al-Karim. 2003. al-Judhur al-Tarikhiyyah li al-Syâri'ah al-Islamiyyah, terj. Kamran Asád, hlm. xi-xii. Yogyakarta: LKiS. 


\section{a. Pengertian}

Menurut Abdul Wahab Khalaf, urf adalah sesuatu yang dikenal manusia dan dijalankan secara biasa, baik berupa perkataan atau perbuatan". ${ }^{3}$ Hal senada diungkapkan oleh Wabhah Zuhaili bahwa "urf adalah sesuatu yang biasa dilakukan oleh manusia dan dijalaninya dari tiap perbuatan yang telah popular diantara mereka, atau juga lafadh yang dikenal dengan sebuah arti khusus yang tidak dicakup bahasa serta maknanya cepat ditanggapi ketika didengarkan". ${ }^{4}$

Istilah 'urf ini sepadan istilah 'adat yang berasal dari akar kata 'ada - ya'udu - 'adatan, yang memiliki arti pengulangan. Secara literal, 'urf dimaknai dengan apa yang telah dikenal. Dan adat memiliki arti pengulangan perbuatan atau praktek yang dilakukan secara berulangulang. Atau aturan (perbuatan dan semacamnya) yang lazim dituruti atau dilakukan semenjak dahulu sehingga sudah menjadi satu kebiasaan. Adat secara terminologis diartikan sebagai norma yang sudah melekat dalam hati akibat pengulang-ulangan, sehingga diterima sebagai sebuah realitas yang rasional dan layak menurut penilaian akal sehat". ${ }^{5}$

Norma tersebut bisa dilakukan oleh individu atau kelompok masyarakat. Secara dasariyah, kedua istilah ini bertemu pada satu titik pengertian, yaitu sesuatu yang diterima akal sehat, tertanam dalam hati dan dilakukan berulang-ulang. Karena pada tataran praktisnya, para fuqaha' tidak membedakan kedua istilah tersebut. Keberbedaan antara 'urf dengan adat yang seringkali dipersoalkan oleh sebagian ulama tersimpul pada dua hal pokok; intensitas keberlakuannya dan kuantitas pelakunya. Jelas, bahwa adat lebih unggul dari pada 'urf pada dua bidang yang dimaksud tersebut.

\section{b. Ketentuan Hukum Adat yang Diterima oleh Fiqh}

Secara umum, terdapat empat syarat bagi sebuah tradisi untuk bisa dijadikan sebagai pijakan hukum ${ }^{6}$ yaitu:

1) Kebiasaan tersebut berlaku konstan (ittira $>$ d) dan menyeluruh, atau minimal dilakukan kalangan mayoritas $(g\} a>l i b)$. Bilapun ada yang tidak mengerjakan, maka itu hanya sebagian kecil saja dan tidak dalam bentuk yang dominan. Yang dimaksud konstan disini adalah

\footnotetext{
${ }^{3}$ Abdul al-Wahhab Khallaf. Masadir al-Tashri' al-Islami fi Ma La Nassa fi hi, 145.

4 Wahbah al-Zuhaili. 828.

5 Zain al-'Abidin bin Ibrahim bin Nujaim. 1993. al-Ashbah wa al-Nazair 'ala Madzhab Abi Hanifah al-Nu'man, 93. Beirut: Dar al-Kutub al-'Ilmiyyah.

${ }^{6}$ Muhammad al-Ruki. 1998. Qawa'id al-Fiqh al-Islami min Khilal Kitab al-Ishraf 'ala Masail al-Khilaf, 218-220.
}

122 JURNAL LISAN AL-HAL 
bersifat umum dan sulit sekali untuk berubah-ubah dari waktu ke waktu.

2) 'Urf sudah terbentuk sebelum atau bersamaan dengan masa penggunaannya. Oleh sebab itu, muncullah sebuah kaidah, La> 'ibrata bi al-'urf al-ta>ri', kebiasaan yang baru muncul itu tidak diperhitungkan. ${ }^{7}$

3) Tidak terdapat ucapan atau pekerjaan yang nyata-nyata bertentangan dengan nilai-nilai substansial 'urf.

4) 'Urf tidak bertentangan dengan teks syari'ah. Artinya 'urf tersebut berupa 'urf Shahih, yaitu bahwa 'urf tersebut tidak sampai menganulir seluruh aspek substansial nas\}. Sebab bila isi substantif nas\} tidak teranulir, maka tidak dinamakan bertentangan dengan nash, karena masih terdapat beberapa unsur nash yang tak tereliminasi. Dengan demikian, unsur-unsur positif 'urf yang berseberangan dengan nas\} bisa dipelihara dan dijadikan pondasi hukum, sementara bagianbagian nash yang tidak terhapus oleh 'urf juga bisa dijadikan acuan hukum.

Tepat dititik inilah kita menemukan urgensi terdalam dari sharat yang diajukan ulama, bahwa adat-istiadat yang dapat diadopsi hanyalah adat yang tidak bertentangan dengan dalil nash.

\section{c. Pola Akomadasi}

Rekrutmen adat-istiadat atau tradisi masyarakat Arab ke dalam hukum Islam, dalam tradisi fuqah dilakukan dengan tiga pola. Pertama, syari ah mengambil sebagian tradisi itu dan membuang sebagian lainnya. Kedua, Islam mengambil sebagian dan membuang sebagian yang lain, dengan melakukan penambahan dan pengurangan di sana-sini. Dan ketiga, Islam mengadopsinya secara utuh tanpa adanya perubahan bentuk dan identitasnya. Tapi dari ketiga pola adopsi ini, Islam sendiri sama sekali tidak mengubah hukum-hukum inti, konsep-konsep dasar, apalagi nas\}nas\} qat\}'i -nya.

Dari sudut pandang yang berbeda, 'Abd al-Karim Zaydan juga menganalisa tiga pola penyerapan syari ah terhadap budaya mayarakat Arab. ${ }^{8}$ Pola pertama, Nabi saw. saw. banyak mengadopsi budaya-budaya Arab yang bernilai positif sementara kebiasaan-kebiasaan negatif ditinggalkan. Kedua, hakikat penerapan adat sebenarnya merupakan

${ }^{7}$ Zain al-'Abidin bin Ibrahim bin Nujaim. Op. Cit, 101.

8 'Abd. Al-Karim Zaydan. 1994. al-Wajiz fi Ushul al-Fiqh, 254-255. Amman: Maktabah al-Bathair.

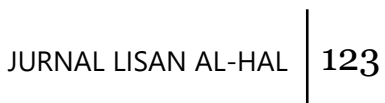


pemberlakuan dalil-dalil shar'i> itu sendiri. Artinya, bila adat itu dijadikan acuan maka sejatinya hukum yang diancang adalah hukum yang didasarkan pada dalil nash (selain al-Quran-Hadits), seperti ijma>, istihsa>n, mas\}lah\}ah mursalah, maupun sadd al-dzari'ah. Contoh tradisi yang berdasarkan ijma' dapat kita lihat pada pemberlakuan akad istisna yakni transaksi pembelian barang yang hendak dibuat. ${ }^{9}$ Hal ini diamini, karena akad tersebut telah menjadi satu kebutuhan masyarakat yang cukup mendesak. Jika tradisi yang menjadi kebutuhan dasar ini dihapus, maka masyarakat akan menghadapi banyak kesulitan. Selama tradisi itu baik (Shahih) dan menolak mafsadah, maka selama itu pula pemeliharaan atas tradisi merupakan bagian dari maslahah mursalah. Yang ketiga, bahwa para fuqaha pada perkembangan berikutnya lebih bersikap kooperatif dan apresiatif terhadap 'urf yang berkembang di masyarakat. Hal ini menjadi bukti bahwa pemeliharaan atas tradisi merupakan sesuatu yang tidak bertentangan dengan ajaran Islam. ${ }^{10}$

\section{d. Akar Perselisihan di Kalangan Ulama tentang Adat}

Walaupun hukum adat dapat dikompromi oleh fiqh, dikalangan ulama fiqh sesungguhnya terjadi perbedaan pendapat dalam menjadikan adat sebagai sumber hukum Islam. Perbedaan tersebut tidak lepas dari pandangan teologis klasik yang menjawab permasalah al-husn dan alqubh. Pertanyaan yang seringkali diajukan adalah; apakah sebuah persoalan dianggap baik (hasan) dan buruk (qabih) merupakan otoritas akal ataukah hanya semata-mata milik Syari'?. Kalau otoritas akal, siapa yang lalu berhak menghakiminya ? Dalam hal ini, perdebatan yang mengemuka di kalangan pakar Islam diarahkan pada dua hal; sebelum pengutusan rasul (qabl al-bi'thah) dan setelah pengutusan rasul (ba'da albi'thah). Di lingkup ba'da al-bi'thah, persoalan sebenarnya sudah usai, dalam arti telah menemukan konvergensi antara yang pro dan kontra.

Persoalan utamanya justru terpusat pada ma qabla al-bi'thah atau apa yang lebih dikenal dengan masa fatrah; masa dimana tidak terdapat pengutusan Rasul. Dalam hal ini, perdebatan panjang seputar teologisnya berkenaan dengan siapa sesungguhnya yang layak menjadi hakim; akal ataukah sha $>$ ri'? Siapa pula yang berhak menetapkan barometer bagi perbuatan baik (sebagai sesuatu yang layak dipuji) dan buruk (sebagai sesuatu yang patut dicemooh dan dihina) di masa fatrah?

9 'Abd al-Karim Zaydan. Op. Cit, 255 dan Wahbah al-Zuhaili. Op. Cit, 35.

10 'Abd. Al-Karim Zaydan. Op. Cit, 255.

$124 \mid$ JURNAL LISAN AL-HAL 
Paling tidak, terdapat tiga golongan mainstream yang bertolak belakang satu dengan yang lainnya; golongan Asy’ariyyah, Mu'tazilah dan Maturidiyyah. Pertama, golongan Ash'ariyyah. ${ }^{11}$ Mereka menegaskan bahwa tidak terdapat pemutus (al-hakim) di masa fatrah, sehingga koridor baik dan buruk, saat itu, tidaklah terukur. Artinya bahwa persoalan baik dan buruk, di masa fatrah haruslah di-pending. Dalam kaitan ini, Ash”ariyyah mengembalikan semua perbuatan mukallaf; baik dan buruk semata-mata karena faktor shara: Bukan berarti bahwa Ash"ariyyah menolak penggunaan akal sama sekali karena akal tetap saja digunakan. Namun, kedudukan akal tidak lebih hanya sekedar penegasan atas apa yang telah diabsahkan oleh dua sumber primer syari ${ }^{2}$ ah; Al-Qur'an dan alHadits. ${ }^{12}$ Akal, dalam pandangan Asy`ariyyah, tetap harus tunduk pada aturan-aturan baku sumber primer tersebut dan tidak boleh bertentangan secara diametral terhadapnya. Dengan perkataan lain, akal berfungsi di level kedua, setelah keberlakuan sumber primer tersebut.

Kedua, golongan Mu'tazilah. Golongan yang selalu antagonis dengan golongan Ash”ariyyah ini berpendapat bahwa persoalan dimana shara” belum diturunkan, dikembalikan pada akal. Menurut mereka, akal sesungguhnya memiliki potensi untuk menakar perbuatan baik dan buruk, tanpa harus melalui shara'. Sebab, secara tabi'i, dalam kondisi apapun akal sebenarnya mampu untuk menjustifikasi perbuatan yang baik dan yang buruk. Dalam kasus kejujuran (al-s\}idq) dan kebohongan (al-kadzb) misalnya, seseorang melalui akal sehatnya -tanpa harus dituturi Syara sebetulnya mampu untuk membedakan; mana yang baik dan mana yang buruk. Kalau pun kemudian datang syara', ia hanya berposisi sebagai legitimator atas apa yang telah diputusi oleh syara' Lebih jauh, Mu'tazilah menegaskan bahwa perbuatan mukallaf terbagi dalam tiga bentuk; alhasan al-dzatiy, al-qabih al-dzatiy dan mutaraddid baina al-hasan wa alqabih. Yang dimaksud al-hasan al-dzatiy adalah suatu hal yang diperintahkan untuk mukallaf, kendati ia tidak mengetahui syara : Karena itu, al-hasan al-dzatiy, mau tidak mau, merupakan hal yang semestinya diperintah syara: Sementara, al-qabih al-dzatiy adalah perbuatan yang dilarang untuk dikerjakan mukallaf, mekipun ia tidak mengetahui syara: Demikian halnya, al-qabih al-dzatiy, sama dengan al-hasan al-dzatiy, merupakan larangan yang seharusnya dari syara: Dan, terakhir, yang

11 Golongan Asy'ariyyah -atau dalam istilah lain Asya'irah- adalah kelompok yang dinisbatkan kepada Abu al-Hasan 'Ali bin Isma'il al-Asy'ari (260-324 H). Lihat Khalid bin 'Abd al-Latif bin Muhammad Nur. 1995. Manhaj Ahl al-Sunnah wa al-Jama'ah wa Manhaj al-Asha'irah, jld. I, 28. Medinah: Maktabah al-Ghuraba' al-Athariyyah.

12 Muhammad Abu Zahrah. Op. Cit, 73. 
mutaraddid antara al-hasan dan al-qabih adalah perkara yang boleh (yajûzu) diperintah dan juga boleh dilarang. ${ }^{13}$

Ketiga, kalangan Ma>turidiyyah ${ }^{14}$ berpendapat agak mirip dengan Mu'tazilah. Menurut mereka, termasuk di dalamnya kalangan Hanafiyyah, bahwa perbuatan itu terbagi ke dalam; hasan dzatiy dan qabih dzatiy. Allah swt. tidak akan memerintah persoalan yang qabih dzatiy dan tidak akan melarang persoalan yang mengandung nilai hasan dzatiy. Sedangkan, persoalan yang berada di kisaran hasan dan qabih, itu mengikuti perintah Allah swt. Namun begitu, kalangan $\mathrm{H}$ \}anafiyyah misalnya, tidak berhenti pada landasan akal semata, melainkan juga tetap mendasarkan pada nash atau mengarahkannya pada nash. Rujukan mereka, kendati berpandangan demikian, tetap pada nash berikut metode mengarahkan padanya seperti qiyas, dan maslahah mu'tabarah al-mushabbahah yang bersesuaian dengan nash atau yang lebih populer disebut dengan istihsan. ${ }^{15}$

Domain teologis ini, sedemikian berpengaruh pada bangunan madhhab yang digagas para imamnya. Oleh karena itu, madhhab yang terang-terang menggunakan 'urf sebagai dalil hukum hanyalah madhhab Hanafi dan Maliki. Jika Madhhab Hanafi memasukkan jalur 'urf ke dalam istihsan, maka madzhab Maliki, selain mengkategorikan secara mandiri sebagai sumber hukum Islam, juga memasukkan sebagai bagian dari sumber hukum lain, yaitu maslahah mursalah.

Sementara itu, dua madhhab besar yang lain; Syafi i dan $\mathrm{H}$ \}anbali, cenderung menolak 'urf sebagai sumber hukum Islam. Namun begitu, tanda-tanda bahwa mereka sejatinya juga menerima 'urf, tidak dapat diragukan lagi. Kalau pun tidak pada landasan filosofisnya, maka merekapun sesungguhnya menerima dan melegalkan operasionalisasi 'urf dalam bangunan madhhabnya. Misalnya madzhab Hanafi yang membangun fiqhnya berlandaskan pada 'urf. Al-Nu'man ibn Thabit ibn Zuti yang dikenal dengan Abu Hanifah (80-150 H/ 699-767 M) menggunakan tradisi Kufah sebagai dasar penetapan hukumnya yang diakomodir dalam konsep istihsan. Bahkan Abu Hanifah menolak qiyas demi memenangkan 'urf. ${ }^{16}$ Muhammad bin al-Hasan al-Shaibani (w. 189 H/ 805 M) -sahabat dan pengikut Abu Hanifah-, mengemukakan bahwa aturan interpretasi yang sifatnya teoritis dan menunjukkan undangundang berasal dari 'urf. ${ }^{17}$ Dengan kaidah-kaidah seperti al-Thabit bi al-

13 Muhammad Abu Zahrah. Op. Cit, 71.

${ }^{14}$ Kelompok ini dipelopori oleh Abu Mansur Muhammad al-Maturidi (w. 333 H).

15 Muhammad Abu Zahrah. Op. Cit, 72-73.

16 Muhammad bin Ahmad Abu Sahl Al-Sarkhasi. Op. Cit, jld. XII, 199.

17 Muhammad bin al-Hasan al-Shaibani. 1953. Al-Siyar al-Kabir, jld. I, 194-198.

$126 \mid$ JURNAL LISAN AL-HAL 
'Urf ka al-Thabit bi an-Nashi (ketetapan hukum yang diderivasikan dari 'urf/kebiasaan sama halnya dengan ketetapan yang diambil dari nash), alMa'ruf 'Urfan ka al-Mashrut Shartan (pengetahuan yang diperoleh dari kebiasaan sama halnya dengan sesuatu yang disharatkan),dan lain sebagainya, didapati terlahirkan dari rahim madhhab Hanafi. Abu Yusuf (w. 182 H/ 795 M), misalnya dikabarkan telah mengatakan bahwa adat menjadi bahan pertimbangan utama dalam sistem hukum Hanafiah, terutama ketika nash yang jelas tidak dapat diketemukan. ${ }^{18}$ Bahkan Abu Yusuf sesekali harus mengambil jalan berbeda dengan gagasan imamnya, karena kultur dan waktu yang berbeda. ${ }^{19}$

Tidak berbeda dengan golongan $\mathrm{H}$ \}anafiyah, para ahli hukum Malikiyah menerima prinsip-prinsip adat sebagai sumber otoritas hukum yang pasti. Karya utama Imam Malik seperti al-Muwattha', alMudawwanah dan Fath al-'Ali al-Malik, memasukkan doktrin hukumnya dengan berlandaskan kemaslahatan umum (al-maslahat al-'ammah). ${ }^{20}$ Ungkapan-ungkapan seperti 'praktek yang kita setujui' yang digunakan Imam Malik dalam al-Muwattha' merupakan bukti pandangannya bahwa 'urf ahli Madinah merupakan salah satu sumber hukum yang paling kuat. Masih menurut Imam Malik, terdapat tiga praktek 'urf yang memiliki kekuatan hukum; 1) praktek penduduk Medinah ('amal ahl al-Madinah); 2) praktek para pakar di Medinah; dan 3) praktek para pemegang otoritas politik. Berdasar fakta inilah, Malik membebaskan para wanita ningrat dari pelaksanaan aturan Qur'an yang memerintahkan para ibu untuk menyusui anak-anak mereka ${ }^{21}$, karena adat para wanita yang berkedudukan tinggi di Madinah tidak menyusui bayi mereka. ${ }^{22}$ Sedemikian terang di sini, bahwa posisi adat, dalam pandangan pemikir besar dalam madzhab Maliki ini, berada dalam puncak klimaks.

Kairo: Syirkah Musahamah.

18 Ibn al-Humam. 1937. Syarh Fath al-Qadir. jld. V, 282-283. Kairo: Matba'at Mustafa Muhammad.

${ }^{19}$ Jaih Mubarok. 2000. Sejarah dan Perkembangan Hukum Islam, 76. Bandung: PT. Remaja Rosdakarya.

20 Salah satu ciri khâs metodologi istinbat al-ahkam-nya Imam Malik, adalah pendasaran fiqh semata-mata pada 'urf ahli Madinah. Dalam skala prioritas landasan sumber hukumnya, 'urf lebih dimenangkan dari pada hadits Ahad. Lihat Yasin Dutton. 2003. Asal Mula Hukum Islam; Al-Qur'an, Muwattha' dan Praktik Madinah, 75-106. Jogyakarta: Penerbit Islamika.

21 QS. al-Baqarah, [2], 233.

22 Yasin Dutton. Op. Cit, 1-31. 
Kendati posisi Imam Shafi i nyata-nyata menentang 'urf sebagai landasan sumber hukum Islam, tapi tataran praktis ia ditengarai mempertimbangkan 'urf dalam menetapkan sebuah hukum. Hal ini bisa dilihat ketika dia meralat pendapatnya, dari qawl qadim kepada qawl jadid. Beberapa pengikutnya justru mengambil term 'urf sebagai yang turut serta memberi andil dalam pembentukan hukum Islam. Sebut saja, 'Izz al-Din ibn 'Abd. Al-Salam al-Sulami (w. 660 H) menyatakan bahwa bila dalam sebuah masyarakat terdapat satu 'urf yang berlaku sedemikian rupa sehingga dianggap sama dengan pernyataan lisan, maka 'urf tersebut dapat menggantikan ucapan dalam tindakan hukum. Hal itu dilakukan semata-mata karena memperhatikan faktor kultur dan setting sosial yang berbeda $^{23}$. Dalam tataran aplikasinya, Jalaluddin al-Suyuti (w. $911 \mathrm{H} /$ $1505 \mathrm{M}$ ) demikian cerdas melakukan sejenis verifikasi atas prinsip hukum yang dilandaskan pada 'urf. Slogan al-'Adah Muhakkamah, jelas-jelas merupakan pembenaran atas dasar 'urf. ${ }^{24}$ Kendati, 'urf di sini, tidaklah dalam pengertian yang utuh dan sofistik, akan tetapi lebih pada pengertian kebiasaan (yang bersifat personal).

Selanjutnya, Imam Ahmad Ibn Hanbal (164-241 H) yang mempunyai nama lengkap Abu 'Abdillah Ahmad ibn Hanbal ibn Hilal ibn Asad al-Shaibani al-Marwazi, perancang madhhab Hanabilah, terangterang menyatakan keengganan menggunakan 'urf sebagai rancangbangun metodologi madhhabnya. Namun begitu, para pengikutnya seperti Ibnu Qudamah (w. $620 \mathrm{H}$ ), tegas-tegas menggunakan keberadaan adat sebagai sumber hukum. Ia pun menguatkan aturan-aturan fiqhnya dengan merujuk pada adat. ${ }^{25}$ Demikian halnya, Ibnu Taimiyah, dalam al-Fatawa

23 Kamil Musa mengatakan bahwa qawl qadim adalah pendapat Syafi i yang didiktekan dan ditulis di Irak pada tahun $195 \mathrm{H}$ dan pengembaraannya ke Hijaz serta kembali ke Irak tahun 198 H. Lalu tahun 199 H, Imam Syafi i mengadakan perjalanan ke Mesir dan menyaksikan adat dan kegiatan mu'amalah yang berbeda dengan di Irak dan Hijaz. Sejak itulah Shafi'i mengeluarkan fatwa yang berbeda yang kemudian dikenal dengan Qawl jadid. Kamil Musa. 1989. al-Madkhlm ila al-Tasyri' al-Islami, 158. Beirut: Muassasah al-Risalah. Lihat juga, Ahmad Amin. 1974. Duha al-Islam, 231. Kairo: Maktabah al-Nahdah al-Misriyyah.

24 Bahkan al-Rafi'i menyatakan bahwa al-Syafi'i kadang-kadang mengikuti pengertian yang diberikan oleh bahasa (lughatan) bila penunjukkan maknanya jelas (zhahir) karena pengertian tersebut merupakan yang asal. Namun, pada satu waktu dia mengikuti 'urf jika 'urf tersebut telah berlangsung lama dan berlaku secara tetap (muttarid). Lebih jelasnya, lihat Jalaluddin Ábd. Al-Rahman bin Abi Bakr al-Suyuti. 1965. al-Asybah wa al-Nazhair fi al-Furu', 63-71. Surabaya: al-Hidayah.

${ }^{25}$ Abu Muhammad Ábdillah bin Ahmad Ibn Qudamah. 1984. al-Mughni, jld. VI, 485. Beirut: Dar al-Fikr. 
al-Kubra, juga sering melandaskan pikiran-pikiran hukumnya pada adat. Ketika ia menggunakan kata safar sebagai salah satu hal yang mengijinkan mukallaf melakukan rukhsah shalat, maka istilah tersebut dikembalikan pada makna kebiasaan setempat.

Dengan demikian, dalam kontruksi fiqh semua madhhab sesungguhnya menerima 'urf, atas dasar firman Allah :"Jadilah engkau orang yang pema'af dan suruhlah orang-orang mengerjakan dengan 'urf, serta berpalinglah dari orang-orang yang bodoh".26

Yang dimaksud dengan 'urf dalam ayat di atas adalah kebiasaankebiasaan manusia dan hal-hal yang biasa mereka lakukan sehingga jiwa mereka menjadi tenang dan damai. ${ }^{27}$ Hal ini juga didasarkan pada perkataan Ibnu Mas'ud yang kemudian dikenal dengan Hadits mauqûf 28 , yaitu : "Apa yang dipandang oleh orang-orang Islam sebagai sesuatu yang baik, maka menurut Allah hal itu juga baik".29

Dari deskripsi ini, jelaslah bahwa persoalan 'urf mendapat tempat yang elegan dalam diskursus keIslaman. 'urf-meskipun sebagian pihak secara malu-malu mengintrodusirnya sebagai bagian dari sumber hukum Islam-tak pelak kehadirannya dipastikan meniscayakan. Maka tak heran kalau kemudian terdapat sebuah maxim (kaidah): "Adat kebiasaan itu bisa dijadikan dasar hukum".30

\section{Fiqh versus Hukum Negara}

Diskurus tentang hubungan fiqh dan hukum negara tidak dapat dilepaskan dari diskursus agama dan negara. Risalah Nabi yang dilakukan di Makkah tidak membahas tentang posisi agama dan negara. Akan tetapi pada fase Madinah muncul beberapa embrio yang menjeleskan kaitan antara agama dengan sebuah kekuasaan Pemerintahan (negara). Tradisi kehalifahan yang dilakukan oleh khulafa al-rashidin, dan dilanjutnya tradisi dinasti oleh sahabat dan penerusnya menggambarkan adanya penyatuan antara agama dan negara. Sehingga hukum agama secara

26 QS. Al-A'râf, [7], 199.

${ }^{27}$ Muhammad al-Zuhaili. Op. Cit,172.

${ }^{28}$ Hadits mauqûf adalah Hadits yang disandarkan kepada shahabat Nabi, berupa perkataan ataupun perbuatan, baik sanadnya bersambung maupun terputus. Lihat Muhammad bin 'Alawi al-Maliki al-Hasani. 1982. al-Manhlm al-Latif fi Ushul al-Hadits alSyarif, hlm. 83. Jeddah: Sahar.

${ }^{29}$ Abu 'Abdillah Ahmad bin Hanbal al-Syibani. 1994. Musnad al-Imam Ahmad bin Hanbal, jld. I, hlm. 379. Beirut: Dar Ihya' al-Turats al-'Arabi.

${ }^{30}$ Jalaluddin Ábd. Al-Rahman bin Abi Bakr al-Suyuti. Op. Cit, hlm. 63 dan Zain al'Abidin bin Ibrahim bin Nujaim. Op. Cit, 93. 
otomotis menjadi hukum negara. Meskipun begitu, runtuhnya kekuasaan Turki Usthmani pada abad ke 19 membukan diskursus relasa agama dan negara. Atas dasar itu, dikalangan umat Islam muncul tiga teori, yakni teori negara agama, teori negara sekular, dan teori simbiotik yang dinilai cukup relevan diterapkan dalam konteks negara bangsa.

\section{Teori Negara Agama}

Teori negara agama menyatakan bahwa negara dalam kondisi apapun tidak dapat dipisahkan dari agama. Ini sebagaiman secara konseptual, agama juga tidak dapat dipisahkan begitu saja dari selukbeluk politik. Sebab, menurut teori ini, semua upaya pemikiran sorang Muslim tentang moral dan politik bisa dipastikan mempunyai dasar-dasar keagamaannya. Dengan ungkapan lain, menurut paradigma pemikiran ini, negara merupakan lembaga politik dan keagamaan sekaligus. Al-Maududi, misalnya, menyodorkan teori teokrasi di mana pemerintahan sebuah negara diselenggarakan atas dasar kedaulatan Tuhan. ${ }^{31}$

Menurut Yusuf al-Qardlawi, pemikir Islam asal Mesir, menegaskan bahwa negara Islam adalah negara madani yang ditegakkan berdasarkan pemilihan, baiat, dan musyawarah. Kepala negara bertanggung jawab di hadapan rakyatnya. Setiap individu masyarakat berhak untuk menasihati penguasa, menyuruhnya berbuat baik dan melarangnya berbuat munkar. Penguasa menurut pandangan Islam terikat oleh ketentuan-ketentuan, nilai-nilai, dan hukum-hukum syariat. Sebaliknya penguasa tidak bisa seenaknya membuat hukum sendiri, berfoya-foya, otoriter, anti kritik, dan lain sebagainya. Setiap pribadi muslim boleh menentang bila disuruh penguasa melakukan sesuatu yang berlawanan dengan syariat. ${ }^{32}$

Dengan demikian, negara Islam sesungguhnya tidak identik dengan negara teokrasi yang selalu mengatasnamakan Tuhan. Lebih tepatnya negara Islam disebut negara teo-demokrasi yang memadukan unsur ketuhanan dengan demokrasi. Hal ini dapat dimengerti lantaran teks agama sendiri tidak berbicara secara mendetail (tafshili) dan partikular (juz'i) soal seluk-beluk perpolitikan sehingga cara merumuskannya memerlukan pembahasan dan permusyawaratan di tingkat rakyat maupun penguasa. Mengabaikan permusyawaratan justru bertentangan

31 Dr. H. Abd. Salam, M.A., Kata Pengantar buku Aspects of The Islamic State: Religious Norms and Political Realities karya Monouchehr Paydar, Ph.D., dalam edisi Indonesia, Legitimasi Negara Islam: problem Otoritas Syari'ah dan Politik Penguasa, hlm. x. 32 Adian Husaini, M.A. dan Nuim Hidayat, Islam Liberal, 15.

$130 \mid$ JURNAL LISAN AL-HAL 
dengan prinsip-prinsip politik dalam Islam seperti disebutkan dalam teks agama.

Namun demikian, teori negara Islam yang secara lebih dominan berkembang di masyarakat bukan sekedar menggabungkan unsur ketuhanan dengan demokratisasi. Sebaliknya, negara Islam lebih dipahami sebagai formalisasi Islam dalam wujud dasar negara dan pemberlakuan syariat islam secara legal dan formal. Kelahiran teori negara Islam dengan pengertian ini beriringan dengan munculnya gerakan fundamentalisme Islam yang dimotori oleh beberapa tokoh semisal Abul A'la al-Maududi (Pakistan), Hasan al-Banna (Mesir), dan Sayid Qutub (Mesir). Gerakan ini mulanya diproyeksikan untuk merespons modernisasi barat yang eksesnya dinilai telah merambah dunia Islam.

Hasan Hanafi, Pemikir Islam dari Mesir, menegaskan bahwa gerakan ini berusaha menegakkan dan merealisasikan syariat Islam serta membangun sistem yang Islami dengan menolok sistem-sistem non-Islam yang berlaku selama ini. Lebih jauh gerakan ini berusaha mendasarkan realitas kehidupan pada dasar islam mengingat dasar-dasar yang lain dianggap tidak sah. Karena itu, jika ia dipergunakan sebagai dasar maka realitas menjadi rusak seperti yang terjadi selama ini. Gerakan ini meyakini bahwa berbagai masalah yang timbul dewasa ini disebabkan manusia tidak menerapkan ajaran Tuhan dengan sebenar-benarnya. Jika ingin masalah-masalah tersebut bisa diatasi maka satu-satunya cara adalah menerapkan syariat Tuhan meskipun realitas menolaknya. ${ }^{33}$

Gerakan ini, masih menurut Hasan Hanafi, mempunyai kecenderungan membuat analisis persoalan berdasarkan ajaran syariat yang bersifat ideal, bukan pada realitas. Mereka menghendaki realitas mengikuti idealisme ajaran syariat, bukan sebaliknya, yakni syariat mengikuti realitas. Dengan ungkapan lain, dalam kondisi apapun perkembangan realitas harus mengacu secara formal pada ajaran agama. Dari perspektif inilah gerakan ini lalu disebut fundamentalisme. ${ }^{34}$

Dalam pandangan Islam, antara negara, agama, pemimpin, individu dan pemerintah sesungguhnya tidaklah bisa dipisahkan satu sama lain. Doktrin dan ajaran-ajaran Islam melingkupi dan mendominasi seluruh kehidupan tiap muslim. Ia membentuk sikap, kepercayaan, tingkah laku, dan secara pasti menjadi sebuah way of life (jalan hidup) bagi para pengikutnya. Dengan demikian, bukan merupakan sebuah kekeliruan jika

33 Moh. Nurhakim, Islam, Tradisi, dan Reformasi: Pragmatisme Agama dalam Pemikiran Hasan Hanafi, 149.

34 Ibid. 149. 
seseorang mengklaim bahwa semangat dari keyakinan yang kuat menampakkan dirinya dalam setiap aspek kehidupan seorang muslim meskipun mereka telah menyimpang dari ajaran-ajaran otentik agamanya. Islam merupakan sebuah doktrin politik religius yang didasarkan pada persaudaraan universal. Negara ideal Islam adalah komunitas iman atau ummah, tanpa memandang ras atau pertimbangan geografis. ${ }^{35}$

\section{Teori Negara Sekuler}

Teori sekular ini identik dengan paham pemisahan antara agama dan negara. Paradigma teori ini menyatakan bahwa agama tidak menekankan adanya kewajiban mendirikan negara. Di lihat dari akar sejarahnya, gagasan teori ini berasal dari warisan perkembangan peradaban barat sejak abad pertengahan. Saat itu, ajaran bible dianggap mengandung hal-hal yang kontradiktif dengan akal-budi manusia. Revolusi ilmu pengetahuan yang sedang dirintis barat dianggap bertentangan dengan ajaran bible. Dominasi gereja saat itu dianggap menghambat kemajuan penelitian ilmiah. ${ }^{36}$

Pertentangan antara akal dan bible mulai mengkristal pada zaman modern. Orang barat menyebut sejarah zaman pertengahan sebagai dark ages (zaman kegelapan). Arus modernisasi yang begitu kuat dan tak dapat dibendung ini kemudian menyebabkan barat menafsirkan bible dengan tafsiran baru. Saat inilah bergulir gagasan sekularisasi. Teologi sekular mengkritik posisi gereja dengan teologi lamanya yang dianggap ideal. Intinya, gagasan sekularisasi muncul karena ketidaksanggupan doktrin dan dogma agama untuk berhadapan dengan peradaban barat yang terbentuk dari beragam unsur. Hasilnya, muncul pemikiran bahwa untuk menghadapi sekularisasi, ajaran agama harus disesuaikan dengan pandangan hidup sains modern. ${ }^{37}$

Dalam politik, sekularisasi diistilahkan dengan desakralisasi yang bermakna bahwa politik tidaklah sakral. Maksudnya, unsur-unsur rohani dan agama harus disingkirkan dari dunia politik. Termasuk peran agama terhadap institusi politik harus dipisahkan juga. Segala macam kaitan antara kuasa politik dan agama dalam masyarakat apapun tidak boleh berlaku karena bagi masyarakat sekular tidak seorangpun dapat memerintah atas nama otoritas agama. Karena itu, dalam masyarakat

35 Manouchehr Paydar, Ph.D., Aspects of the Islamic States: Religious Norm and Political Realities, 41.

${ }^{36}$ Adnin Armas, M.A., Pengaruh Kristen - Orientalis terhadap Islam Liberal, 3.

37 Ibid, 4 - 5.

$132 \mid$ JURNAL LISAN AL-HAL 
sekular tidak tergambarkan diberlakukannya penerapan syariat atau ajaran agama dalam kehidupan politik. Gagasan sekularisasi dengan makna desakralisasi seperti ini mula-mula diintrodusir ole Harvey Cox ${ }^{38}$, kemudian dirujuk oleh Robert N. Bellah, ${ }^{39}$ dan terakhir istilah ini lebih dipopulerkan lagi di tanah air oleh alm. Nurcholish Madjid. ${ }^{40}$

Gagasan sekularisasi mulai dikonversi oleh para pemikir muslim pasca kejatuhan kerajaan Islam Turki Utsmani pada abad XIX. Lalu menemukan momentumnya pada abad XX dengan munculnya ketokohan Ali Abdur Raziq dari Mesir dan Mushthafa Kemal Attaturk dari Turki. Gagasan Ali Abdur Raziq tentang sekularisasi banyak dituangkan dalam bukuny, al-Islam wa Ushul al-Hukm. Ali Abdur Raziq menolak khilafah islamiyyah atau daulah islamiyyah (negara islam) bagi kaum muslimin. Bahkan ia tak segan-segan meng-qiyas-kan hadits-hadits nabi tentang imamah, khilafah, bai'ah dan yang sejenisnya dengan pernyataan Yesus Kristus tentang masalah hak Kaisar dan hak Tuhan. ${ }^{41}$

Sejalan dengan Raziq, Attaturk juga melancarkan konsep yang sama dalam bidang kenegaraan, yaitu pemisahan agama dari negara. Menurut Attaturk, apabila agama dipergunakan untuk memerintah masyarakat maka ia akan senantiasa dipergunakan sebagai alat dalam tangan raja diktator untuk menghukum. Pemisahan agama dengan negara akan menyelamatkan bangsa dari malapetaka. Pemisahan agama dari negara dimulai pada tahun 1928 dengan menghapus pasal 2 Konstitusi Turki yang menyebutkan bahwa agama negara adalah Islam. Sebelumnya, tahun1924, Biro Syaikh al-Islam dan Kementerian Syari'at serta Mahkamah Syari'at dihapuskan. Proses ini dimaksudkan untuk menggusur otoritas syari'at dan meletakkan kedaulatan rakyat secara mutlak. Negara tidak ada lagi hubungannya dengan agama. Sembilan tahun kemudian, 1937, prinsip sekularisme dimasukkan ke dalam konstitusi Turki, sehingga resmilah Turki menjadi negara republik sekular. ${ }^{42}$

Belakangan ini gagasan sekularisasi sering digulirkan untuk merespons tuntutan-tuntutan paham fundamentalisme. Dalam upaya mengkounter paham fundamentalisme yang mengedepankan pendirian negara Islam, kalangan intelektual muslim cenderung menggunakan konsep-konsep eropa mengenai pemisahan yang tegas antara agama dan otoritas politik. Paham sekularisasi seperti ini mengalami resistensi cukup

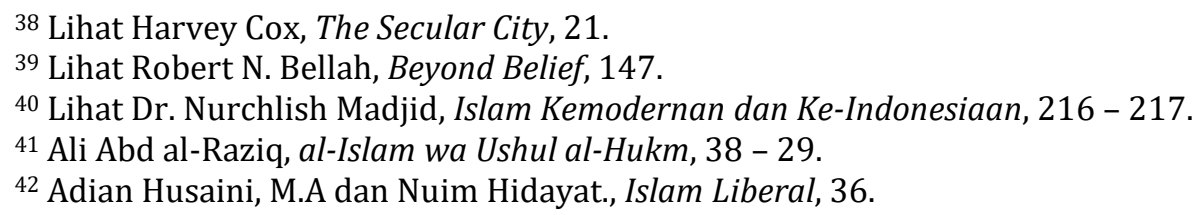


tinggi lantaran mengabaikan isu legitimasi kultural bagi negara Islam. Mereka bukan saja mengabaikan klaim kalangan fundamentalis yang teguh dengan pendirian untuk membangun sebuah negara Islam, tetapi juga menyerukan kepada masyarakat untuk meninggalkan fondasi-fondasi agama dan budaya islam.

Gagasan menerapkan sekularisme untuk masyarakat Islam didorong oleh sikap penolakan mereka terhadap agenda fundamentalisme Islam. Mereka khawatir akan adanya dampak akibat penerapan Islam politik bagi politik nasional dan relasi internasional. Namun ironisnya, gagasan tersebut justru menjadikan kelompok yang mereka serang bertambah kuat. Dibanding dengan sekularisme eropa sebagai satusatunya alternatif bagi negara islam dan aplikasi syari'at, masyarakat muslim tentu akan memilih yang kedua ini meskipun sebenarnya secara konseptual sulit diterima dan prakteknya sulit diwujudkan. ${ }^{43}$ Teori simbiotik (negara bangsa)

Isu negara bangsa (nation state) mulai mengemuka dan diwacanakan oleh banyak kalangan seiring kehadiran imperialisme dan kolonialisme barat memasuki wilayah kekuasaan Islam. Ini terjadi setelah berakhirnya kerajaan Islam Turki Uthmani pada abad ke-19. Dalam situasi negara yang multi-etnik, multi-ras, multi-kultural, dan multi-agama lalu muncul teori simbiotik menyangkut hubungan komplementer dan timbal balik antara negara dan agama. Teori ini mengedepankan hubungan harmonisasi keduanya (agama dan negara). Di satu sisi, negara memerlukan panduan etika-moral dari ajaran agama. Sementara di sisi lain, agama memerlukan instrumen negara untuk mengaplikasikan pesanpesan moral yang tertuang dalam ajarannya.

Dalam konteks negara bangsa, teori negara agama dan negara sekular sama-sama memiliki kelemahan dalam tataran implementasinya. Negara agama akan mengalami hambatan cukup berarti ketika berhadapan dengan realitas pluralisme yang menjadi ciri khas dalam negara bangsa. Seperti kita tahu bahwa negara bangsa adalah persekutuan masyarakat di suatu daerah tertentu dan diurus oleh suatu pemerintahan yang sah. Dalam negara bangsa, fungsi negara adalah untuk mengorganisir kemasyarakatan yang berdiri di atas kesepakatan-kesepakatan dari berbagai macam golongan, suku, bangsa, ras, agama dan lain sebaginya.

43 Abdullahi Ahmed An-Na'im, Islam Politik dalam Kancah Politik Nasional dan Relasi Internasional, dalam Peter L. Berger (ed.), Kebangkitan Agama Menantang Politik Dunia. 206 - 207.

$134 \mid$ JURNAL LISAN AL-HAL 
Komunitas Islam yang belakangan ini banyak menjelma menjadi negara bangsa karena faktor keragaman dan kemajemukan penduduknya cukup relevan mengadopsi teori simbiotik dalam pembentukan negara dan penyelenggaraan pemerintahan. Kelebihan teori ini tak lain adalah keluwesannya dalam mengantisipasi perubahan masyarakat dan perkembangan ilmu ketatanegaraan yang cenderung semakin komplek dan tidak mungkin dibendung. Selain menentang pemisahan negara dan agama, teori ini juga tidak mengharuskan umat Islam untuk mengibarkan agama. Apa yang terpenting menurut teori ini, bagaimana umat Islam mampu mengapresiasi nilai-nilai ajaran agama dalam kehidupan yang serba majemuk, baik dalam bidang budaya, warna kulit, suku, dan bahkan agama.

Mengimplementasikan pesan-pesan ajaran agama (fiqh) yang dituangkan secara makro dan garis besar dalam kitab suci sudah merupakan pelaksanaan kedaulatan Tuhan dalam pengertiannya yang substantif. Kenyataannya, berbagai teks agama yang bertalian dengan penegakan negara dan penyelenggaraan pemerintahan umumnya bersifat kulli atau ijmali, yakni mengatur secara universal dan strategis, misalnya menyangkut kesejahteraan dan kemaslahatan, penegakan hukum secara adil tanpa diskriminasi, mengedepankan musyawarah serta tidak bersikap dzalim dan tirani, dan lain semacamnya.

\section{Simpulan}

Islam adalah agama yang akomodatif. Akomodasi Islam terhadap segala sesuatu berada di luar Islam dalam kerangka mewujudkan kemaslahatan bagi umat manusia. Karena itu, hukum adat dan juga hukum negara dapat diakomodir oleh Islam selama tidak bertentangan dengan visi Islam untuk mewujudkan kemaslahatan dan menolak mara bahaya. Dan begitu, Islam tidak menjadi kaku dan mudah diterima oleh masyarakat, sebagaimana dakwah yang dilakukan oleh Rasulullah Saw di tanah Arab dan walisongo di bumi Indonesia.

\section{Daftar Pustaka}

Ami>n, Ahmad, D\}uha> al-Islam, Kairo: Maktabah al-Nahdah al-Misriyyah, 1974.

Dutton, Yasin, Asal Mula Hukum Islam; Al-Qur'an, Muwattha' dan Praktik Madinah, Jogyakarta: Penerbit Islamika, 2003.

al-Hasani, Muhammad bin 'Alawi al-Maliki, al-Manhul al-Lathif fi Ushul alHadits al-Syarif, Jeddah: Sahar, 1982. 
Ibn al-Humam, Syarh Fath al-Qadir, Kairo: Matba'at Mustafa Muhammad, 1937.

Ibn Nujaim, Zain al-'Abidin bin Ibrahim, al-Ashbah wa al-Nazhair 'ala Madzhab Abi Hanifah al-Nu'man, Beirut: Dar al-Kutub al-'Ilmiyyah, 1993.

Ibn Qudamah, Abu Muhammad Ábdillah bin Ahmad, al-Mughni, Beirut: Dar al-Fikr, 1984.

al-Karim, Khalil 'Abd, al-Judhur al-Tarikhiyyah li al-Syari'ah al-Islamiyyah, terj. Kamran Asád, Yogyakarta: LkiS, 2003.

Mubarok, Jaih, Sejarah dan Perkembangan Hukum Islam, Bandung: PT. Remaja Rosdakarya, 2000.

Musa, Kamil, al-Madkhal ila al-Tasyri' al-Islami, Beirut: Muassasah alRisalah, 1989

An-Na'im, Abdullahi Ahmed, Islam Politik dalam Kancah Politik Nasional dan Relasi Internasional, dalam Peter L. Berger (ed.), Kebangkitan Agama Menantang Politik Dunia.

Nurhakim, Moh., Islam, Tradisi, dan Reformasi: Pragmatisme Agama dalam Pemikiran Hasan Hanafi.

Nur, Khalid bin 'Abd al-Latif bin Muhammad, Manhaj Ahl al-Sunnah wa alJama'ah wa Manhaj al-Asha>'irah, Medinah: Maktabah al-Ghuraba' alAthariyyah, 1995.

Paydar, Manouchehr, Aspects of the Islamic States: Religious Norm and Political Realities.

al-Ruki, Muhammad, Qawa'id al-Fiqh al-Islami min Khilal Kitab al-Ishraf 'ala Masail al-Khilaf, 1998.

al-Suyuthi, Jalaluddin Ábd. Al-Rahman bin Abi Bakr, al-Asybah wa alNazhair fi al-Furu', Surabaya: al-Hidayah, 1965.

al-Shaibani, Muhammad bin al-Hasan, Al-Syarh al-Kabir, Kairo: Syirkah Musahamah, 1953.

Tim Santru Ma'had Aly, Cendekiawan Fiqh Berbicara, Situbondo: Ma'had Aly, tt.

Zaydan, 'Abd. Al-Karim, al-Wajiz fi Ushul al-Fiqh, Amman: Maktabah alBathair, 1994.

136 JURNAL LISAN AL-HAL 